necessary duplicates, and worn-out materials. Procedures regarding deletion need to be explicit for weeding and disposing of such materials. Prompt attention must be given to damaged materials so that repairs and replacement (including rebinding of printed materials or replacement of portions of projected or recorded materials) are handled systematically, along with prompt action to replace important items, including those discovered to be missing.

15. The Learning Resources Unit functions as an archive for historical information and documents concerning the college itself.

An effort should be made to locate, organize, and house institutional archives to the extent defined by the administration.

\section{SERVICES}

A. Users of Learning Resources have the right to expect:

1. That facilities, materials, and services are available and accessible to meet demonstrated instructional needs for their use regardless of location;

2. That an atmosphere be provided which allows sensitive and responsive attention to their requirements;

3. That professional staff be readily available for interpretation of materials and services and for consultation on instructional development;

4. That physical facilities be properly maintained to make use comfortable and orderly;

5. That requests for scheduling, circulation, distribution, and utilization of materials and related equipment be handled expeditiously;

6. That acquisition, production, and organization of materials meet educational, cultural, and personal needs.
7. If an institution is conducting classes in offcampus locations, careful planning and funding must be provided to ensure that equal services are available to those programs.

\section{Interagency Cooperative ACtivities}

A. Cooperative arrangements for sharing of resources are developed with other institutions and agencies in the community, region, state, and nation.

To provide the best possible service to the students and faculty in the two-year college, close relationships with other local institutions and agencies and with institutions of higher education in the area are essential. Through consortia, media cooperatives, and loan arrangements, institutions can share resources. The college may need to make arrangements so that its students may use the area facilities and resources. When an undue burden is placed on a neighboring institution, financial subsidy may be appropriate.

B. The institution is willing to consider participation in cooperative projects, such as shared cataloging, computer use, and other services which may be mutually beneficial to all participants.

By cooperative planning much expense and wasteful duplication can be avoided in the community and region. Learning Resources personnel and institutional administrators need to be alert to cooperative activities of all kinds and to be willing to explore the possibilities of participation for their own institution.

C. Responsibility for the collection and preservation of community history and for the accumulation of other local and statistical data is shared with other institutions and is coordinated with them.

\title{
Proposed Bylaws of the Law and Political Science Section
}

Editor's Note: The following proposed bylaws will be voted on by LPSS members at the 1982 ALA Annual Conference in Philadelphia.

\section{Article I. Name}

The name of this organization is the Law and Political Science Section of the Association of College and Research Libraries.

\section{Article II. Object}

The Section shall represent librarians in the field of law and political science. It will act for ACRL in cooperation with other professional groups in regard to those aspects of library service that require special knowledge of law and political science.

\section{Article III. Membership}

Any member of ACRL may elect membership in the Section. Every personal member has the right to vote and is eligible to hold office.

\section{Article IV. Meetings}

The Section shall hold an annual meeting at the time and place of the Annual Conference of the American Library Association. Other meet- 
ings may be called at the discretion of the Executive Committee. Ten members constitute a quorum for any meeting of the Section.

\section{Article V. Officers}

Sec. 1. The officers of this Section shall be a chair, Vice-chair/chair-elect, a secretary and two members-at-large.

Sec. 2. All officers shall serve terms ending at the adjournment of the annual meeting. The chair-elect serves as vice-chair for one year. At expiration, or earlier in case of a vacancy in the office of chair, the chair-elect succeeds to the office of chair and serves until the expiration of the term for which elected. The secretary is elected for a term of two years. The members-atlarge are elected for two-year staggered terms. A vacancy in other offices shall be filled by election, except for secretary, which shall be filled by an appointment made by the chair.

\section{Article VI. Committees}

The Executive Committee shall consist of the elected officers. The Executive Committee shall serve as the Program Committee. The chair may appoint additional members to the Program Committee from the membership-at-large for one year. The chair may appoint committee chairmen for specific problems and projects which have been approved by the membership.

\section{Article VII. Representative to other bodies}

The Executive Committee may appoint and charge a representative of the Section to other sections or bodies, as appropriate.

\section{Article VIII. Nominations and Elections}

The Section chair shall appoint a Nominating Committee of at least three members and designate one member as chair. The Nominating Committee shall choose a slate of two candidates for each elective office. All nominees must be members of the Section and must consent to candidacy.

Elections shall be conducted by mail ballot. For each office, the candidate receiving a plurality of the votes cast shall be elected. Ties will be determined by vote of the Executive Committee.

\section{Article IX. Amendments}

Amendments to these Bylaws may be proposed in writing to the Executive Committee by a member or members of the Section. To become effective amendments must be approved by a vote of the membership.

\section{Article X. General Provisions}

Wherever these Bylaws make no specific provisions, the organization of and procedures in the Section shall correspond to those set forth in the ACRL Constitution and Bylaws.

\section{Article XI. Temporary Provisions}

These Bylaws shall take effect upon the adjournment of the meeting at which they are adopted.

\section{CLIP Notes \#3 Published}

A new College Library Information packet (CLIP) has been published by ACRL. CLIP Notes \#3-81 was sponsored by the ACRL College Libraries Section Committee on Continuing Education and is entitled Job Descriptions. The packet presents general information on various levels of library job descriptions currently in use, plus a comprehensive list of theoretical and methodological sources. The cost is $\$ 17.50$ for ACRL members, $\$ 25$ for non-members. Prepayment is required. Please enclose a mailing label and $50 \varnothing$ in postage. Copies may be ordered from ACRL/ALA, 50 E. Huron St., Chicago, IL 60611.

\section{NEW UNITED METHODIST ARCHIVES CENTER}

United Methodist leaders from across the United States gathered on November 21 at Drew University, Madison, New Jersey, to lay the cornerstone of a building that will serve as the church's archives center. The ceremony launched a national campaign to help pay for the $\$ 2.75 \mathrm{mil}$ lion national center, now more than halfway completed.

The holdings of the church's General Commission on Archives and History will be moved to Drew from overcrowded facilities in Lake Junaluska, North Carolina, this summer, and the new archives center is scheduled to open in the fall.

The center will provide 300,000 cubic feet of storage in a two-story underground vault-large enough to accommodate church documents well into the next century. A first floor conference room in mid-eighteenth century decor will contain books, statuettes, and implements associated with the founder of Methodism, John Wesley.

A library will occupy the upper floor, where the Methodist reference and research collections of the university and the general commission will be shelved together for the convenience of users.

Soon to provide free access to the public, the center is only one phase of a three-part, $\$ 14.6$ million library complex now under construction at Drew. The project also includes the construction of a learning center and renovation of the 43year-old Rose Memorial Library. 


\section{Acquisition Librarians.....}

NOW IS THE TIME TO TRY THE BEST SOURCE FOR:

- ANY BOOK IN PRINT

- accurate invoicing

- meaningful reports

- rush order service

- competitive discounts

- plus many other services

CALL TOLL-FREE TODAY

$$
\text { - 1-800-248-1146 - }
$$

In Canada and Michigan:

CALL COLLECT (517) 849-2117
ANY BOOK IN PRINT..... means delivery to your library of "any book in print" from any publisher or distributor in the U.S. or Canada. We have no list of publishers you must check. . . . . . WE ACCEPT THEM ALL!

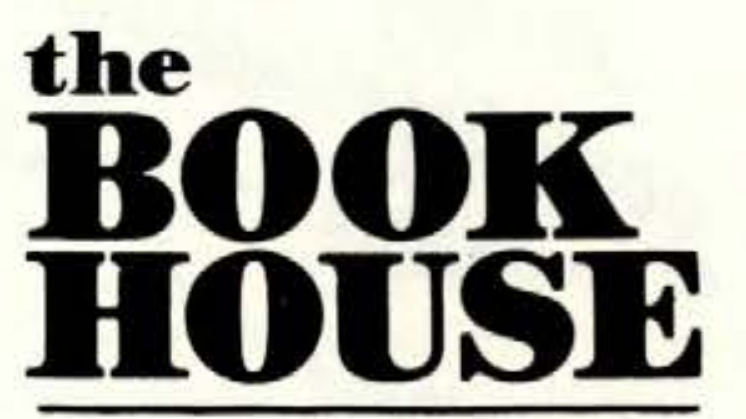

JOBBERS SERVING LIBRARIES WITH ANY BOOK IN PRINT SINCE 1962 208 WEST CHICAGO STREET JONESVILLE, MICHIGAN 49250 SAN 169-3859

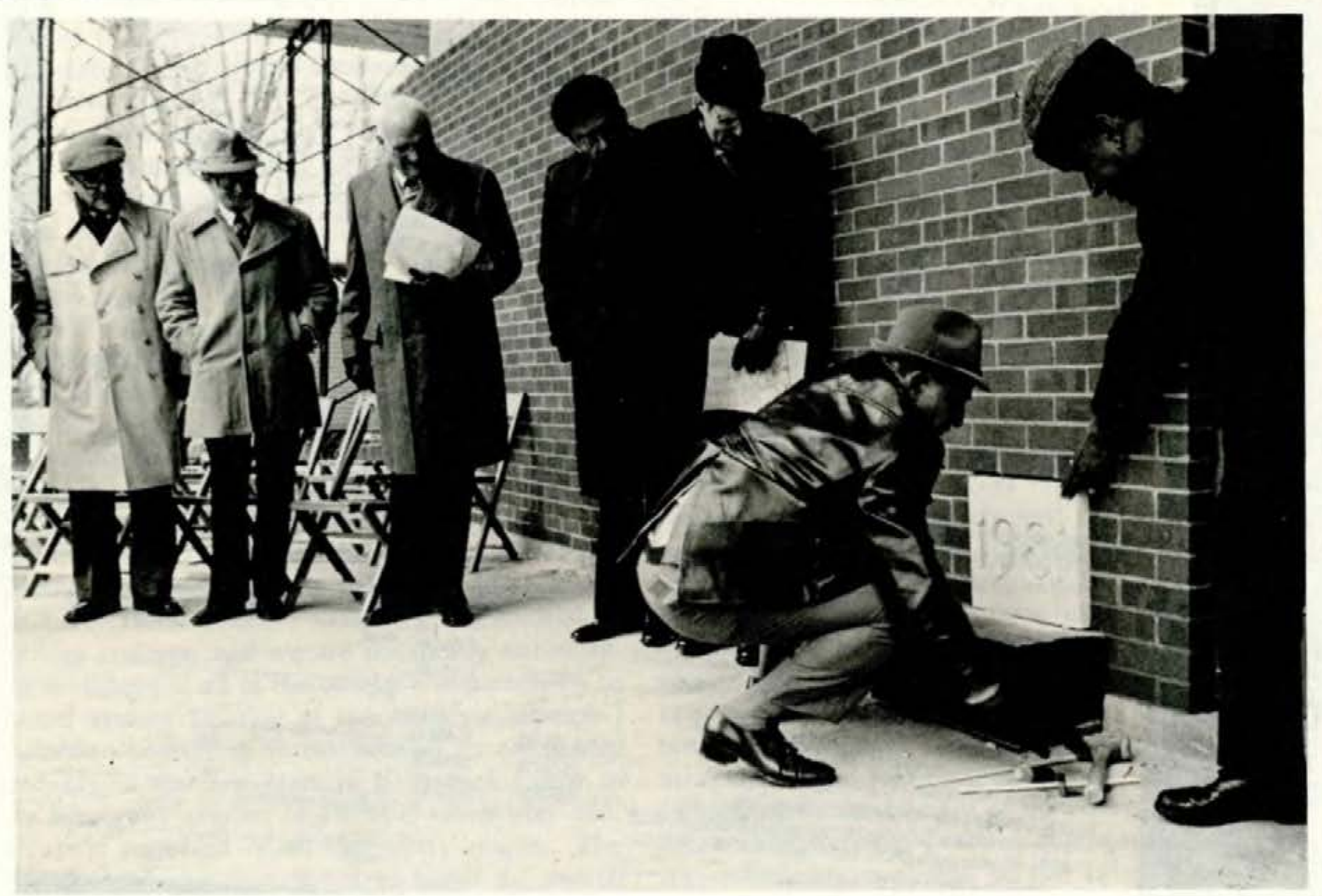

With help from Neu York Bishop Roy C. Nichols (right) mason Louis Dessimone lays the cornerstone of the United Methodist Archices Center. 


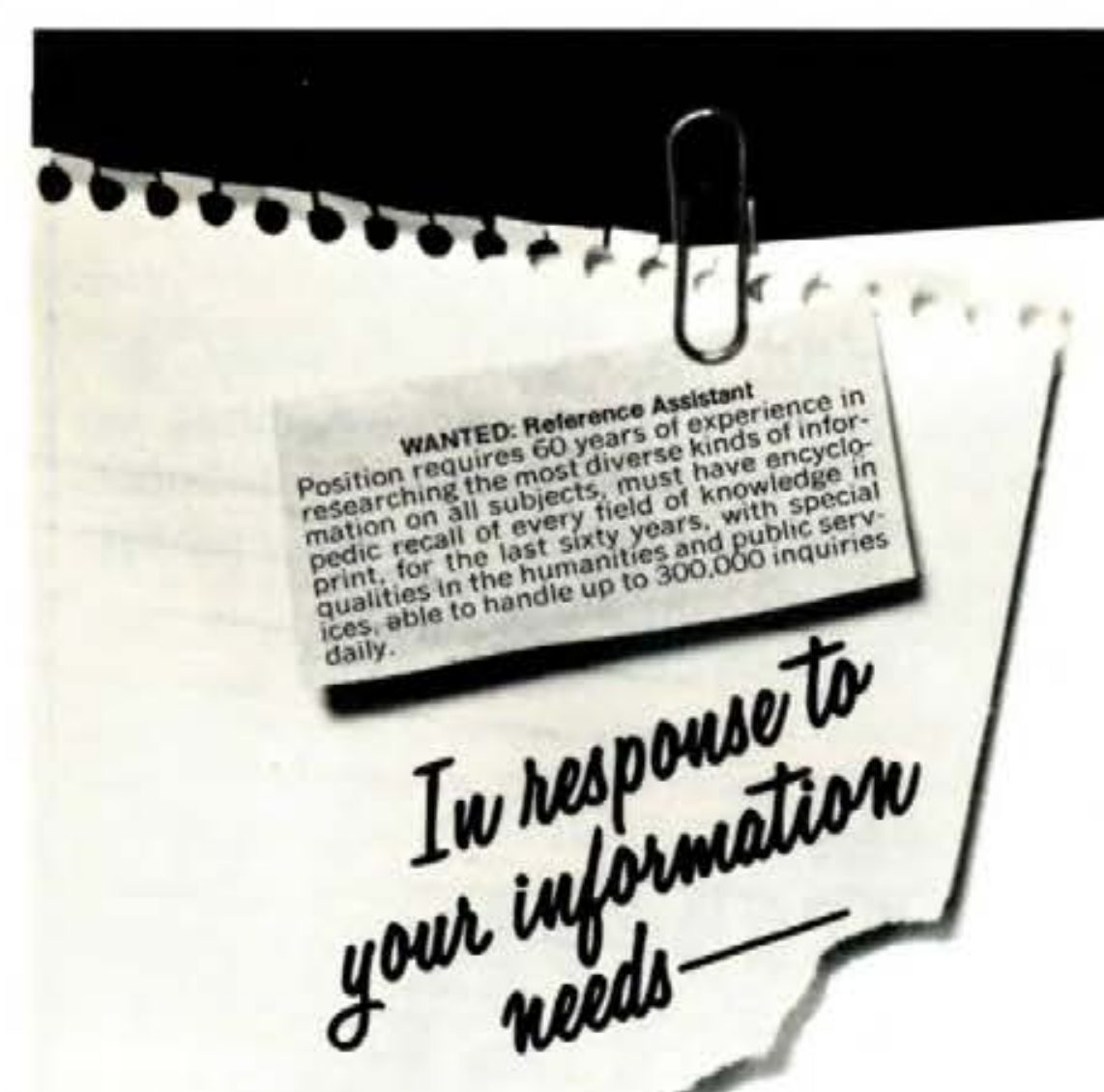

AKA: Exclusive key to the most widely read medium in the world.

Date of Birth: 1981

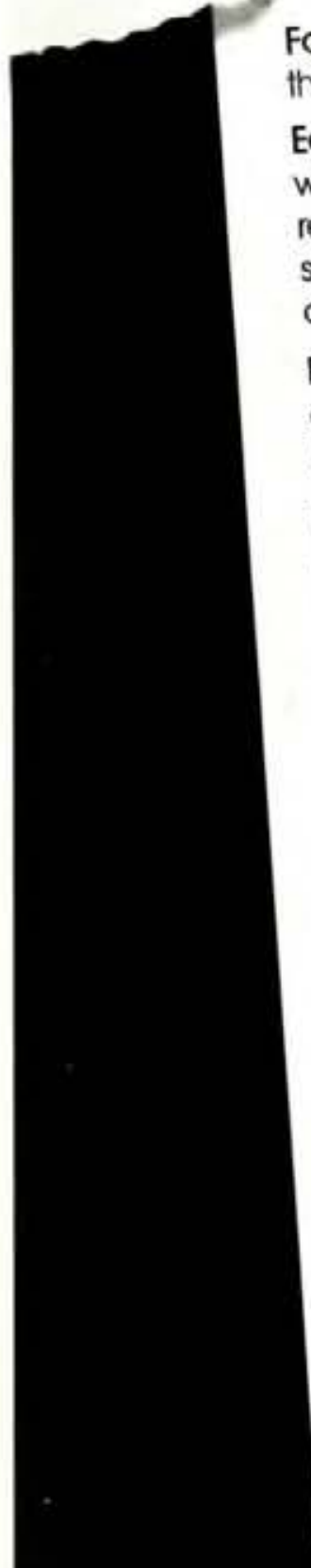

Family Background: Closely related to one of the "first families" of publishing.

Educational/Work Experience: "PhD." in municotion: thesis: brief but thorough world communicalion, intemporary topic with review of nearly every conlem services, philosophy special emphasis

and anecdote.

Provides quick access to a universal "library" of knowledge which previously had required aborious study of widely scattered resources Ready to work on every kind of research ducational, academic, business, professiona. scientific, social, entertainment, etc.

ffers opportunities never before available to library/information scientists and specialists.

\section{Charter subscribers en}

Ploase enter our charter order as follows:

(1) order only)*

口 1982 Subscription (payment with order only

$\square 1980$ Annual (payment with order only)"

1981 Annual (payment with crder only)

$\square 1982$ Subscrip

orders only)"

口 Five-Year Subsciption (quarleries and 1980-1980-1989

口 Ten-Year Subscription (includes0-1984: 10-year anuals, 5 year cumulation.

(9)80-1989)

Ten-year cumulation (1970-1979)

Den-year cumulation (1970-1979)

DSLdy-year cumulation (1922-1981) PaCKAGE

SPECIAL CHARTER SUBSCRIPIION PACKACE 1970 (includes 10 -year subscription; 10 -year cumulation $\$ 105,00$ (includes 10-year subscrion, 1922-1981). You save $\$ 105,00$ 1979: 60-year cumuction 1922-19891. You:

- For orders requiring payment, enclosed s

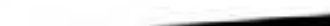

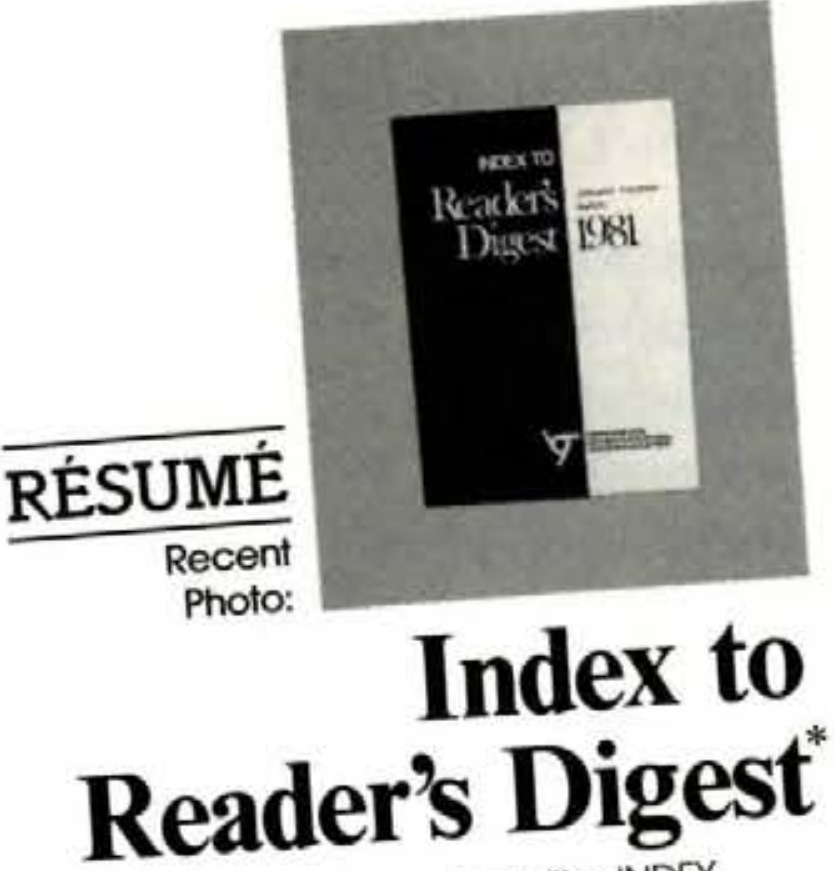

References: Allan Campenter, Editor INDEX TO U.S. GOVERNMENT PERIODICALS; KEN Gilmore. Managing Editor, REisholm, Acting magazine. Dr. Margaret Chiship. University of Director, Sch Washington

Available for Work: Beginning September. very library and office and home world1981: in every library andools for locating answers wide. Will provide own toold and its peoples, to questions about the worl the economy - the about science, medicine, accumulated whole repository of knowledge any subject over sixty years. Makes aimost any subject available almost instantly as well association, inc. -A registered trademark of The f
INTERATIONAL INC.

inforoata inTece, Suite 4602

175 East Delaw 60611

njoy discounts.

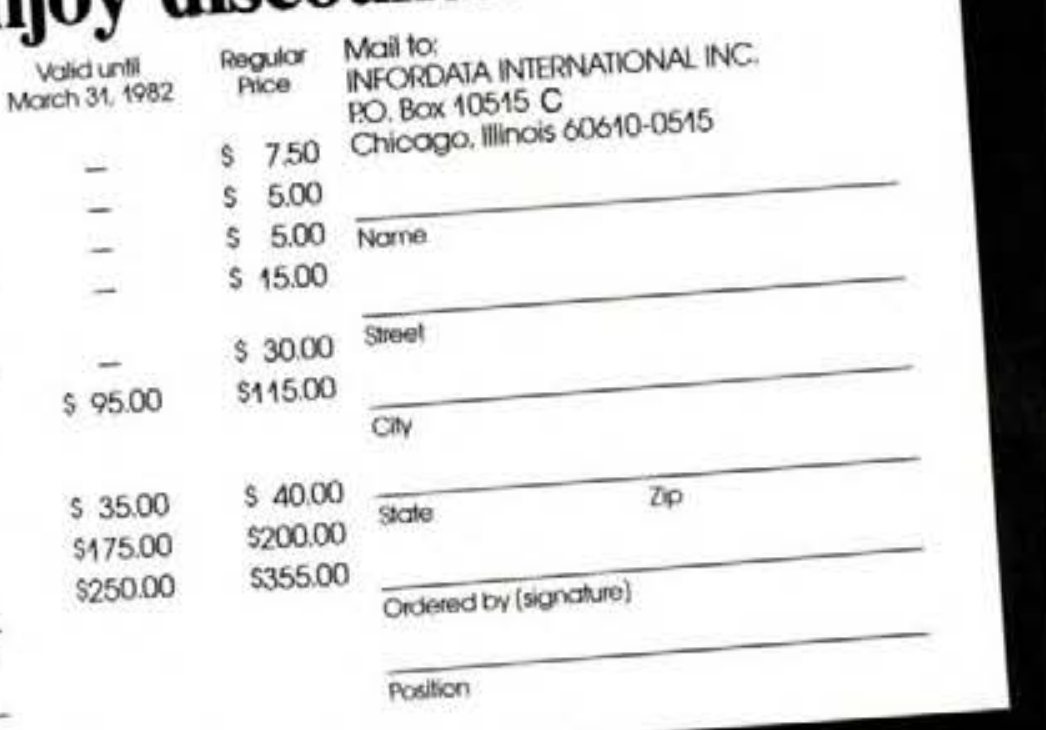

